\title{
Massive axial herniation after posterior fossa infarction following vertebral artery dissection
}

\section{Figure Sagittal T2-weighted MRI scan performed after suboccipital craniectomy showing cerebellar infarction and brain edema within the posterior fossa}

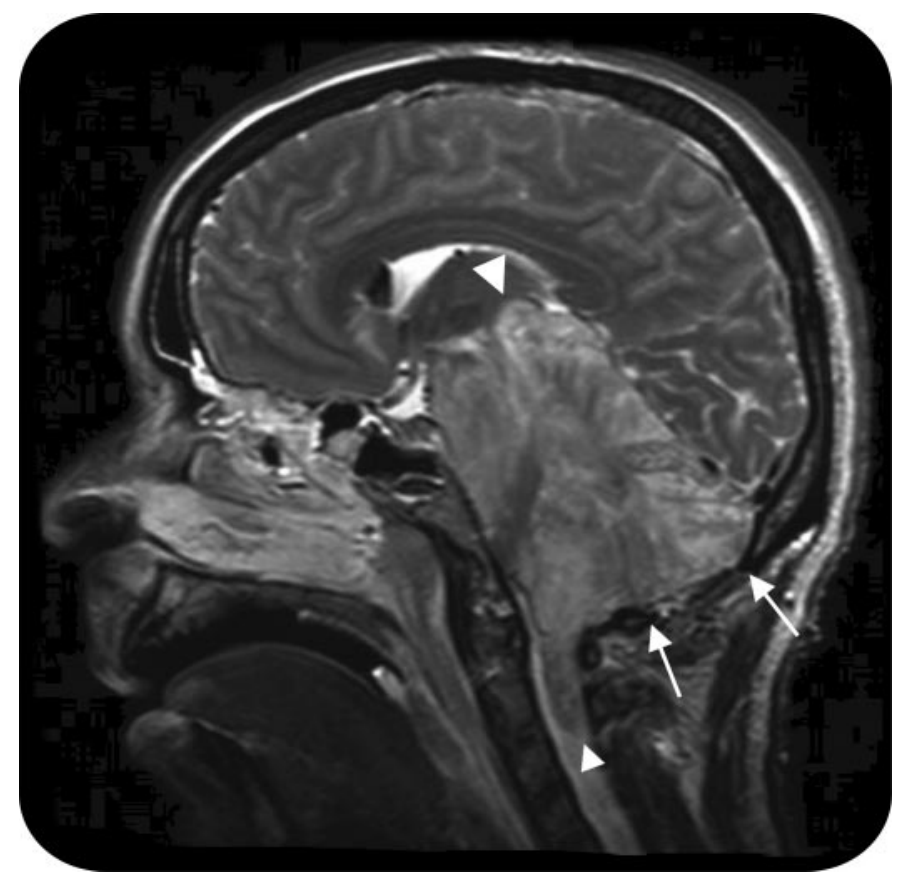

Arrowheads indicate cranial and spinal limits of massive axial cerebellar herniation; arrows represent the borders of the suboccipital craniectomy.

A 35-year-old woman presented with recurrent dizziness, nausea, and headache for 2 weeks. Cranial MRI showed multiple bilateral cerebellar infarctions and caliber changes suggesting a dissection of right vertebral artery. Immediate full heparinization was performed and symptoms completely remitted after 2 days. After subsequent subacute deterioration resulting in unconsciousness 6 hours later, suboccipital craniectomy and extensive osmotic therapy were performed but did not control the massive brain edema in the posterior fossa, which led to death 3 days later (figure). Although vertebral artery dissections usually have benign courses, dramatic exceptions highlight the need for consideration of early suboccipital decompression despite anticoagulation.

Martin Wolz, MD, Alexander Storch, MD, OlafWunderlich, MD, Hauke Schneider, MD, Dresden, Germany

Disclosure: Dr. Wolz has received speaker honoraria from GlaxoSmithKline, Valeant Pharmaceuticals International, Pfizer Inc., Teva Pharmaceutical Industries Ltd., and UCB Schwarz Pharma. Dr. Storch serves on scientific advisory boards for Boehringer Ingelheim, Cephalon, Inc., Valeant Pharmaceuticals International, and UCB Schwarz Pharma; has received funding for travel from Boehringer Ingelheim; serves on editorial boards of Stem Cells, Stem Cells International, The Open Biotechnology Journal, Open Biotechnology Reviews, and the European Neurological Journal; has received speaker honoraria from GE Healthcare, Boehringer Ingelheim, GlaxoSmithKline, Valeant Pharmaceuticals International, Novartis, Solvay Pharmaceuticals, Inc., Lundbeck Inc., and UCB Schwarz Pharma; and has received research support from Boehringer Ingelheim, UCB Schwarz Pharma, the Bundesministerium für Bildung und Forschung, the Deutsche Forschungsgemeinschaft (DFG), the Thyssen Foundation, the Landesstiftung Baden-Württemberg, and the Roland-Ernst Foundation. Dr. Wunderlich reports no disclosures. Dr. Schneider serves as a consultant to Actelion Pharmaceuticals Ltd.

Address correspondence and reprint requests to Dr. Martin Wolz, Department of Neurology, Dresden University of Technology, Fetscherstrasse 74, 01307 Dresden, Germany; Martin.Wolz@Uniklinikum-dresden.de 


\section{Neurology}

\section{Massive axial herniation after posterior fossa infarction following vertebral artery dissection}

Martin Wolz, Alexander Storch, Olaf Wunderlich, et al. Neurology 2009;73;1511

DOI 10.1212/WNL.0b013e3181bf9993

\section{This information is current as of November 2, 2009}

\section{Updated Information \&} Services

Citations

Subspecialty Collections

Permissions \& Licensing

Reprints including high resolution figures, can be found at: http://n.neurology.org/content/73/18/1511.full

This article has been cited by 1 HighWire-hosted articles: http://n.neurology.org/content/73/18/1511.full\#\#otherarticles

This article, along with others on similar topics, appears in the following collection(s):

\section{All Cerebrovascular disease/Stroke}

http://n.neurology.org/cgi/collection/all_cerebrovascular_disease_strok e

All Clinical Neurology

http://n.neurology.org/cgi/collection/all_clinical_neurology

All Headache

http://n.neurology.org/cgi/collection/all_headache

MRI

http://n.neurology.org/cgi/collection/mri

Information about reproducing this article in parts (figures,tables) or in its entirety can be found online at:

http://www.neurology.org/about/about_the_journal\#permissions

Information about ordering reprints can be found online:

http://n.neurology.org/subscribers/advertise

Neurology ${ }^{\circledR}$ is the official journal of the American Academy of Neurology. Published continuously since 1951, it is now a weekly with 48 issues per year. Copyright . All rights reserved. Print ISSN: 0028-3878. Online ISSN: 1526-632X.

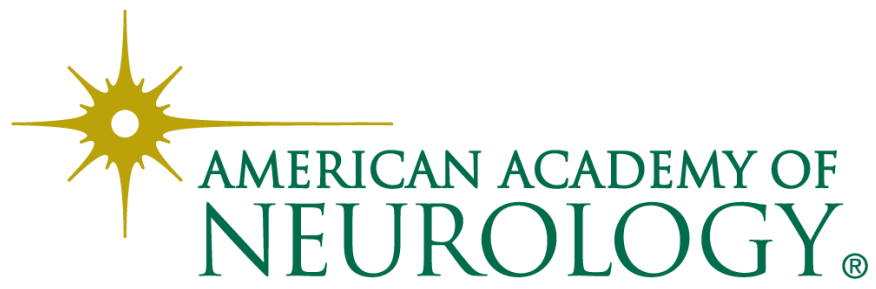

